\title{
Root Morphology, Plant Growth, Nitrate Accumulation and Nitrogen Metabolism of Temperate Lettuce Grown in the Tropics with Elevated Root-Zone $\mathrm{CO}_{2}$ at Different Root-Zone Temperatures
}

\author{
Jie He ${ }^{*}$, Lin Qin, Sing Kong Lee \\ Natural Sciences and Science Education Academic Group, National Institute of Education, \\ Nanyang Technological University, Singapore \\ Email: *jie.he@nie.edu.sg
}

How to cite this paper: He, J., Qin, L. and Lee, S.K. (2016) Root Morphology, Plant Growth, Nitrate Accumulation and Nitrogen Metabolism of Temperate Lettuce Grown in the Tropics with Elevated Root-Zone $\mathrm{CO}_{2}$ at Different Root-Zone Temperatures. American Journal of Plant Sciences, 7, 1821-1833. http://dx.doi.org/10.4236/ajps.2016.714169

Received: July 28, 2016

Accepted: September 26, 2016

Published: September 29, 2016

Copyright $\odot 2016$ by authors and Scientific Research Publishing Inc. This work is licensed under the Creative Commons Attribution International License (CC BY 4.0).

http://creativecommons.org/licenses/by/4.0/ (c) (i) Open Access

\begin{abstract}
This paper investigated the effects of root-zone (RZ) $\mathrm{CO}_{2}$ concentration $\left(\left[\mathrm{CO}_{2}\right]\right)$ on root morphology and growth, nitrate $\left(\mathrm{NO}_{3}^{-}\right)$uptake and assimilation of lettuce plants at different root-zone temperatures (RZT). Elevated RZ $\left[\mathrm{CO}_{2}\right]$ stimulated root development, root and shoot growth compared to ambient RZ $\left[\mathrm{CO}_{2}\right]$. The greatest increase in root growth was observed in plants grown under elevated $\mathrm{RZ}\left[\mathrm{CO}_{2}\right]$ of $50,000 \mathrm{ppm}$. However, RZ $\left[\mathrm{CO}_{2}\right]$ of $10,000 \mathrm{ppm}$ was sufficient to achieve the maximal leaf area and shoot productivity. Lettuce plants exhibited faster shoot and root growth at $20^{\circ} \mathrm{C}-\mathrm{RZT}$ than at ambient (A)-RZT. However, under elevated RZ [CO $\left.\mathrm{CO}_{2}\right]$, the magnitude of increased growth was greater at A-RZT than at $20^{\circ} \mathrm{C}-\mathrm{RZT}$. Compared to $\mathrm{RZ}\left[\mathrm{CO}_{2}\right]$ of $360 \mathrm{ppm}$, elevated $\mathrm{RZ}\left[\mathrm{CO}_{2}\right]$ of $10,000 \mathrm{ppm}$ increased $\mathrm{NO}_{3}^{-}$ accumulation and nitrate reductase activity (NRA) in both leaves and roots. $\mathrm{NO}_{3}^{-}$ concentrations of leaf and root were higher at $20^{\circ} \mathrm{C}-\mathrm{RZT}$ than at A-RZT in all plants. NRA was higher in root than in leaf especially under A-RZT. The total reduced nitrogen (TRN) concentration was significantly higher in plants grown under elevated $\mathrm{RZ}\left[\mathrm{CO}_{2}\right]$ of $10,000 \mathrm{ppm}$ than under ambient $\mathrm{RZ}\left[\mathrm{CO}_{2}\right]$ of $360 \mathrm{ppm}$ with greater concentration in $20^{\circ} \mathrm{C}$-RZT plants than in A-RZT plants. These results imply that elevated RZ $\left[\mathrm{CO}_{2}\right]$ significantly affected root morphology, root and shoot growth and $\mathrm{N}$ metabolism of temperate lettuce with greater impacts at A-RZT than at $20^{\circ} \mathrm{C}-\mathrm{RZT}$. These findings have practical significance to vegetable production by growing the vegetable crops at cool-RZT with elevated $\mathrm{RZ}\left[\mathrm{CO}_{2}\right]$ to enhance its productivity.
\end{abstract}




\section{Keywords}

Lettuce, Nitrate Assimilation, Nitrate Uptake, Root Morphology,

Root-Zone $\mathrm{CO}_{2}$, Root-Zone Temperature

\section{Introduction}

Aerial parts of plant physiology such as photosynthesis are closely associated with morphology and physiological activities of roots, especially under stress conditions [1]-[3]. For example, high temperature limits growth and productivity of temperate crops grown in the tropics, which are mainly due to its poor root development [1]. However, temperate lettuce can now be grown in tropical Singapore at any time of the year by cooling their roots while their shoot are subjected to hot ambient temperature [2] [4] [5]. Except for cooling the RZ, elevated $\mathrm{RZ}\left[\mathrm{CO}_{2}\right]$ also enhanced its productivity [6]-[10]. Effects of elevated $\mathrm{RZ}\left[\mathrm{CO}_{2}\right]$ on photosynthetic gas exchange and water use efficiency have received increased attention recently [11]-[17]. We have previously reported the effects of elevated $\mathrm{RZ}\left[\mathrm{CO}_{2}\right]$ on photosynthesis of aeroponically grown lettuce plants at different RZTs [6]-[10].

In the aeroponic growing system, plant roots have very little interaction with microorganisms. Thus, $\mathrm{RZ}\left[\mathrm{CO}_{2}\right]$ of aeroponically grown plants is much lower than those plants grown in soil [10]. However, plant roots were able to transport $\mathrm{CO}_{2}$ such as $\mathrm{HCO}_{3}^{-}$(dissolved inorganic carbon, DIC) to the aerial parts of plants for photosynthesis regardless of growth medium [11]-[17]. Theoretically, light and $\mathrm{CO}_{2}$ levels are major environmental factors that limit plant growth in the aeroponic systems as water deficit is reduced due to the continuous nutrient and water being supplied to the plant roots [1]. It is well known that the amounts of water and nutrient uptake are determined by both the availability of nutrient solution and the morphology and physiology of the root systems [1] [2]. The changes in root morphology of aeroponically grown plants are closely associated with variations in water and mineral nutrient uptake [1] [2] [18]. Well-developed root systems under cooling RZ environment enhanced water and mineral nutrient uptake, especially the $\mathrm{NO}_{3}^{-}$uptake compared to those roots exposed to high temperatures [1] [2] [18] [19]. The $\mathrm{NO}_{3}^{-}$uptake could be associated with exchange for DIC such as $\mathrm{HCO}_{3}^{-}$. The elevated DIC stimulated respiratory electron transport and increased the incorporation of $\mathrm{NO}_{3}^{-}$into amino acids [11] [20]. In the study of crisp head-type lettuce ( $L$. sativa L. cv. "Wintergreen") grown aeroponically under different $\mathrm{RZ}\left[\mathrm{CO}_{2}\right]$ at two different air temperatures [8], we previously found that $\mathrm{NO}_{3}^{-}$and the total reduced $\mathrm{N}$ (TRN) concentrations of shoots were higher in all plants under elevated $\mathrm{RZ}\left[\mathrm{CO}_{2}\right]$ than under ambient $\mathrm{RZ}\left[\mathrm{CO}_{2}\right]$ at $28^{\circ} \mathrm{C} / 22^{\circ} \mathrm{C}$ (day/night temperature) and $36^{\circ} \mathrm{C} / 30^{\circ} \mathrm{C}$. However, there was very little information on the impacts of elevated $\mathrm{RZ}\left[\mathrm{CO}_{2}\right]$ on root morphology and the key enzyme such as nitrate reductase (NR) under different RZTs. This paper aimed to study the effects of $\mathrm{RZ}\left[\mathrm{CO}_{2}\right]$ with manipulation of RZT on root morphology and growth. The impacts of RZ $\left[\mathrm{CO}_{2}\right]$ under 
different RZTs on $\mathrm{NO}_{3}^{-}$uptake and its assimilation such as NR activity (NRA) were also investigated.

\section{Materials and Methods}

\subsection{Plant Material and Cultural Methods}

After germination, seedlings of lettuce (Lactuca sativa L. cv. "Wintergreen") were transplanted into polyurethane cubes and transferred to the greenhouse for establishment. One week later, they were transplanted to the aeroponic system [1]. Netherlands Standard Composition of nutrient solution was used with $\mathrm{pH}$ maintained at $\sim 6.0$ and an electrical conductivity of $2.2 \mathrm{mS}$. The aerial parts of plants were expose to ambient temperature fluctuating from $26^{\circ} \mathrm{C}-38^{\circ} \mathrm{C}$. Plant roots were subjected to either $20^{\circ} \mathrm{C}$-RZT or fluctuating ambient (A)-RZT. The maximum photosynthetic photon flux density inside the greenhouse was about $1000 \mu \mathrm{mol} \cdot \mathrm{m}^{-2} \cdot \mathrm{s}^{-1}$. Relative humidity was between $65 \%-95 \%$.

\section{2. $\mathrm{RZ}\left[\mathrm{CO}_{2}\right]$ Treatments}

Different RZ $\left[\mathrm{CO}_{2}\right]$ (ambient, $360 \mathrm{ppm}$ and elevated concentrations of 2000, 10,000, $50,000 \mathrm{ppm})$ were imposed on plants at each of the two RZTs $\left(20^{\circ} \mathrm{C}-\mathrm{RZT}\right.$ and A-RZT) after the plants were transplanted for three weeks. The ambient $\left[\mathrm{CO}_{2}\right]$ inside the greenhouse was around 360 to $400 \mathrm{ppm}( \pm 5 \mathrm{ppm})$ while photosynthetic rate was highest between 10.30 to $1100 \mathrm{~h}$. Thus, ambient $\left[\mathrm{CO}_{2}\right]$ was defined as $360 \mathrm{ppm}$. Different elevated $\mathrm{RZ}\left[\mathrm{CO}_{2}\right]$ were supplied to different aeroponic troughs, respectively from compressed air cylinders at $\sim 0.5 \mathrm{~L} \cdot \mathrm{min}^{-1}$ using pre-mixed $\mathrm{CO}_{2}$-air mixtures (SOXAL, Singapore Oxygen Air Liquide Pte Ltd.) [9].

\subsection{Analysis of Root Morphology}

The root morphology was analysed with WIN MAC RHIZO V3.9 programme (Instruments Regent, Canada) equipped with WIN MAC RHIZO scanner (Québec, Canada) two weeks after treatments. The roots of each plant was detached from the shoot and then placed in a tray of water. The water served to spread out the roots and keep them moist. The roots were first scanned before the total length, root tips, surface area and average root diameter was determined by the programme [19].

\subsection{Measurements of Leaf Area, Shoot and Root Fresh Weight (FW) and Dry Weight (DW)}

After elevated $\left[\mathrm{CO}_{2}\right]$ had been supplied to the RZ for one day, similar sizes of the second leaves from the top were labelled immediately from 5 different plants for each treatment. Leaf areas were drawn on the papers between $0800 \mathrm{~h}$ to $0900 \mathrm{~h}$ for every two to three days for 12 days. The leaves drawn on paper were cut and areas were measured using the Area Measurement System (Delta T-Devices Ltd., England). Every 5 days after treatments, whole plants were removed from the aeroponics system and divided into shoot and roots. FWs were recorded immediately and they were then dried to constant mass in an oven at $80^{\circ} \mathrm{C}$ before weighing the DWs on an analytical balance. 


\subsection{Determination of $\mathrm{NO}_{3}^{-}$}

Dried plant tissue of $0.03 \mathrm{~g}$ was ground using a pestle and mortar with deionised water and then incubated at $37^{\circ} \mathrm{C}$ for 2 hours. Sample turbidity was removed by filtration through a $0.45 \mu \mathrm{m}$ pore diameter membrane filter prior to analysis. The $\mathrm{NO}_{3}^{-}$was determined using a Flow Injection Analyser (Model QuikChem 8000, Lachat Instruments Inc., Milwaukee, USA) [19]. The principle of this method was to catalytically reduce $\mathrm{NO}_{3}^{-}$to $\mathrm{NO}_{2}^{-}$and measure the amount of $\mathrm{NO}_{2}^{-}$present by a calorimetric reaction. $\mathrm{NO}_{3}^{-}$is quantitatively reduced to $\mathrm{NO}_{2}^{-}$by passage of the sample through a copperized cadmium column. The $\mathrm{NO}_{3}^{-}$is then determined by diazotizing with sulfanilamide followed by coupling with $\mathrm{N}$-(1-naphthyl) ethylenediamine dihydrochloride. The resulting water soluble dye has a magenta color which is read at $520 \mathrm{~nm}$.

\subsection{Determination of Nitrate Reductase Activity (NRA)}

Leaf or root samples were rapidly frozen in liquid nitrogen after weighed and stored at $-80^{\circ} \mathrm{C}$ until use. The frozen sample $(0.5$ to $1 \mathrm{~g})$ was powdered in liquid nitrogen and ground with $4 \mathrm{ml}$ of extraction buffer, in a mortar with the presence of $0.2 \mathrm{~g} / \mathrm{g} \mathrm{FW}$ insoluble PVP. The extraction buffer contained $0.25 \mathrm{M}$ Tris- $\mathrm{HCl}$ ( $\mathrm{pH} 8.5$ ), $3 \mathrm{mM}$ dithiothreitol (DTT), $10 \mu \mathrm{M}$ flavin adenine dinucleotide (FAD), $1 \mu \mathrm{M}$ sodium molybdate, 1 $\mathrm{mM}$ ethylenediamine-tetra-acetic acid (EDTA) [21]. The extracts were centrifuged at $15,000 \mathrm{~g}$ for $10 \mathrm{~min}$ at $4^{\circ} \mathrm{C}$. NRA was measured immediately in the supernatant. In vitro NADH:NRA assay was derived from Kaiser and Huber [22] with modification. The reaction medium contained $50 \mathrm{mM}$ Hepes- $\mathrm{KOH}$ ( $\mathrm{pH}$ 7.5), $1 \mathrm{mM}$ DTT, $10 \mu \mathrm{M}$ FAD, 10 $\mathrm{mM} \mathrm{KNO} 3,0.2 \mathrm{mM} \mathrm{NADH}, \mathrm{NR}$ extraction, and $15 \mathrm{mM}$ EDTA. The reaction was started by adding of $300 \mu \mathrm{l} \mathrm{NR}$ extraction. Incubation was performed at $25^{\circ} \mathrm{C}$ for 20 $\mathrm{min}$, and the reaction was then terminated by adding sulfanilamide $(1 \%(\mathrm{w} / \mathrm{v})$ in $3 \mathrm{~N}$ $\mathrm{HCl})$ and the naphthylethylene-diamine dihydrochloride $(0.02 \% \mathrm{w} / \mathrm{v})$. After $30 \mathrm{~min}$ at room temperature, the optical density of all the samples was read at $540 \mathrm{~nm}$. The blank was identical to the samples, but the NR extracts were boiled for 5 min before adding into the reaction mixture. NRA was expressed as nmol $\mathrm{NO}_{2}^{-} \mathrm{h}^{-1} \cdot \mathrm{g}^{-1} \mathrm{FW}$.

\subsection{Determination of TRN Concentration}

The concentration of TRN was determined by Kjeldahl digestion of dried samples in concentrated sulphuric acid [23]. The dry sample was placed into a digestion tube with a Kjeldahl tablet and $5 \mathrm{ml}$ of concentrated sulphuric acid. The mixture was then digested in a digestor until the mixture turned clear. After the digestion was completed, the mixture was allowed to cool for $30 \mathrm{~min}$ before it was used to determine $\mathrm{N}$ concentration by a Kjeltec auto 1030 analyser. This result was later used to calculate the $\mathrm{N}$ concentration (mg/g DW) present in the sample.

\subsection{Statistical Analysis}

One-way ANOVA was used to test for significant differences among different RZ $\left[\mathrm{CO}_{2}\right]$ 
treatments. Tukey's multiple comparison tests were used to discriminate the means (MINITAB, Inc., Release 15, 2007).

\section{Results}

\subsection{Root Morphology}

Root morphology analysis was carried out 2 weeks after different $\mathrm{RZ}\left[\mathrm{CO}_{2}\right]$ treatments. It was shown that plants grown under elevated $\mathrm{RZ}\left[\mathrm{CO}_{2}\right]$ had longer total root length (Figure 1(A)), greater number of root tips (Figure 1(B)) and larger root surface area (Figure $1(\mathrm{C})$ ) than under ambient $\mathrm{RZ}\left[\mathrm{CO}_{2}\right]$ at both RZTs with greater values obtained from $20^{\circ} \mathrm{C}-\mathrm{RZT}$ plants than from A-RZT plants. The higher the $\mathrm{RZ}\left[\mathrm{CO}_{2}\right]$ supplied to the plants, the greater the increase in root length, root tip number and root surface area. Elevated $\mathrm{RZ}\left[\mathrm{CO}_{2}\right]$ did not result in any significant changes in average root diameter at either $20^{\circ} \mathrm{C}$-RZT or A-RZT (Figure 1(D)). However, root diameter of A-RZT plants were significantly thicker than those of $20^{\circ} \mathrm{C}$-RZT plants.

\subsection{Leaf Growth, Shoot and Root Productivity}

Expansion of leaf (leaf area) was monitored one day after elevated RZ $\left[\mathrm{CO}_{2}\right]$ had been supplied to the RZ. Leaf expansion of all elevated RZ $\left[\mathrm{CO}_{2}\right]$ plants were faster than that

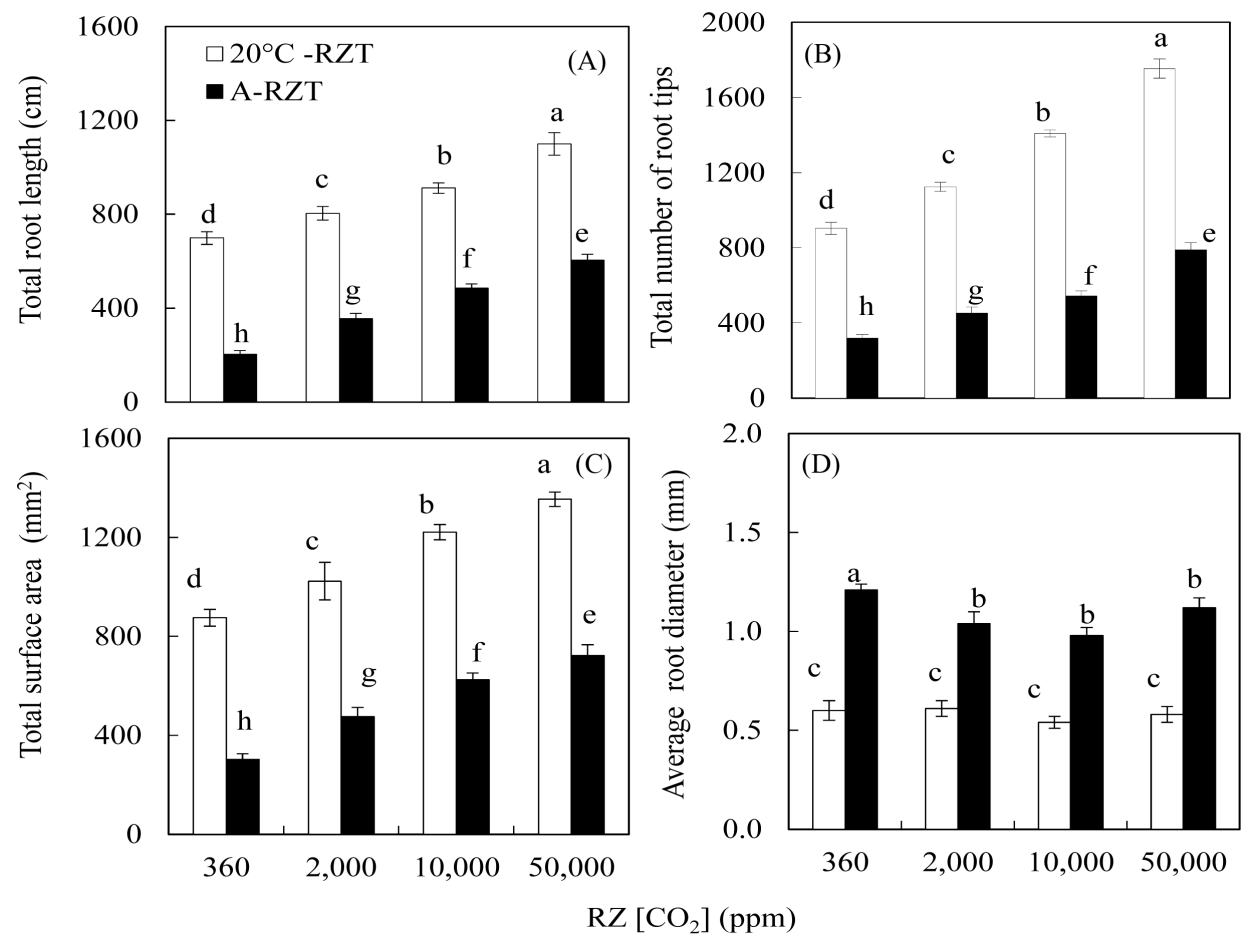

Figure 1. Total root length (A), total number of root tips (B), total surface area (C) and average root diameter (D) of lettuce plants grown under different elevated $\mathrm{RZ}\left[\mathrm{CO}_{2}\right]$ at $20^{\circ} \mathrm{C}-\mathrm{RZT}$ and A-RZT for 3 weeks. Each mean is 5 measurements of 5 different leaves. Vertical bars represent the standard errors. Means with different letters above the bars are statistically different $(\mathrm{P}<0.05)$ as determined by Tukey's multiple comparison test. 
of ambient RZ $\left[\mathrm{CO}_{2}\right]$. There were no significant differences in leaf areas when the roots were exposed to elevated $\mathrm{RZ}\left[\mathrm{CO}_{2}\right]$ of 10,000 and 50,000 ppm and they were much greater than those plants exposed to elevated $\mathrm{RZ}\left[\mathrm{CO}_{2}\right]$ of $2000 \mathrm{ppm}$ (Figure 2). Responses of leaf expansion to different RZ $\left[\mathrm{CO}_{2}\right]$ were similar between $20^{\circ} \mathrm{C}$-RZT (Figure 2(A)) and A-RZT (Figure (2B)) plants. Although leaf growth was much faster under $20^{\circ} \mathrm{C}$-RZT than under A-RZT the magnitude of increased leaf area under elevated RZ $\left[\mathrm{CO}_{2}\right]$ was greater in A-RZT plants than in A-RZT plants.

Both shoot and root productivities were determined every 5 days after elevated RZ $\left[\mathrm{CO}_{2}\right]$ treatments for 20 days. Greater accumulation of biomass in lettuce plants at elevated $\mathrm{RZ}\left[\mathrm{CO}_{2}\right]$ than at ambient $\mathrm{RZ}\left[\mathrm{CO}_{2}\right]$ at both RZTs. By the end of three weeks, RZ $\left[\mathrm{CO}_{2}\right]$ of $10,000 \mathrm{ppm}$ was adequate for maximal shoot production since no further increases in both shoot FW (Figure 3(A) and Figure 3(D)) and DW (data not shown) were obtained when plants were subjected to $\mathrm{RZ}\left[\mathrm{CO}_{2}\right]$ of 50,000 ppm at both RZTs with greater increases in plants grown under A-RZT than under $20^{\circ} \mathrm{C}-\mathrm{RZT}$. However, a greater increase in root FW (Figure 3(B) and Figure 3(E)) and DW (data not shown) in plants grown under $\mathrm{RZ}\left[\mathrm{CO}_{2}\right]$ of 50,000 ppm than of 10,000 ppm. For shoot/root ratio FW (Figure 3(C) and Figure 3(F)) and shoot/root ratio DW (data not shown), there were no changes in plants grown under $\mathrm{RZ}\left[\mathrm{CO}_{2}\right]$ of $50,000 \mathrm{ppm}$ at both RZTs. However, they were much lower than plants grown under other RZ $\left[\mathrm{CO}_{2}\right]$.

\section{3. $\mathrm{NO}_{3}^{-}$Accumulation and Assimilation}

$\mathrm{NO}_{3}^{-}$concentrations of leaf and root were compared between plants grown under ambient RZ $\left[\mathrm{CO}_{2}\right], 360 \mathrm{ppm}$ and elevated $\mathrm{RZ}\left[\mathrm{CO}_{2}\right]$ of 10,000 ppm for 6 and 12 days, respectively (Figure 4). Generally, the concentration of $\mathrm{NO}_{3}^{-}$was higher in roots than in leaf under each given condition after 6 (Figure 4(A)) or 12 (Figure 4(B)) days of treatments. Plants grown under elevated $\mathrm{RZ}\left[\mathrm{CO}_{2}\right]$ of $10,000 \mathrm{ppm}$ had significantly higher concentration of $\mathrm{NO}_{3}^{-}$than under ambient $\mathrm{RZ}\left[\mathrm{CO}_{2}\right]$ of $360 \mathrm{ppm}$ for both leaf and root. Under each $\mathrm{RZ}\left[\mathrm{CO}_{2}\right]$ concentration, plants had higher concentration at $20^{\circ} \mathrm{C}-\mathrm{RZT}$ than at A-RZT.
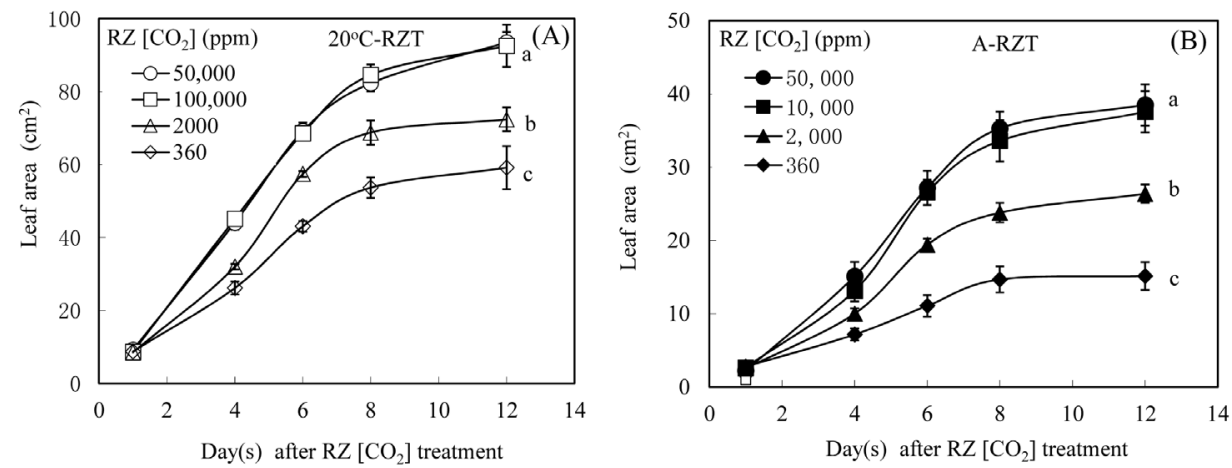

Figure 2. Changes in leaf area of lettuce plans grown under different elevated $\mathrm{RZ}\left[\mathrm{CO}_{2}\right]$ at $20^{\circ} \mathrm{C}-\mathrm{RZT}(\mathrm{A})$ and A-RZT (B). Each mean is 5 measurements of 5 different leaves. Vertical bars represent the standard errors. Means with different letters on day 12 are statistically different $(P<$ 0.05 ) as determined by Tukey's multiple comparison test. 

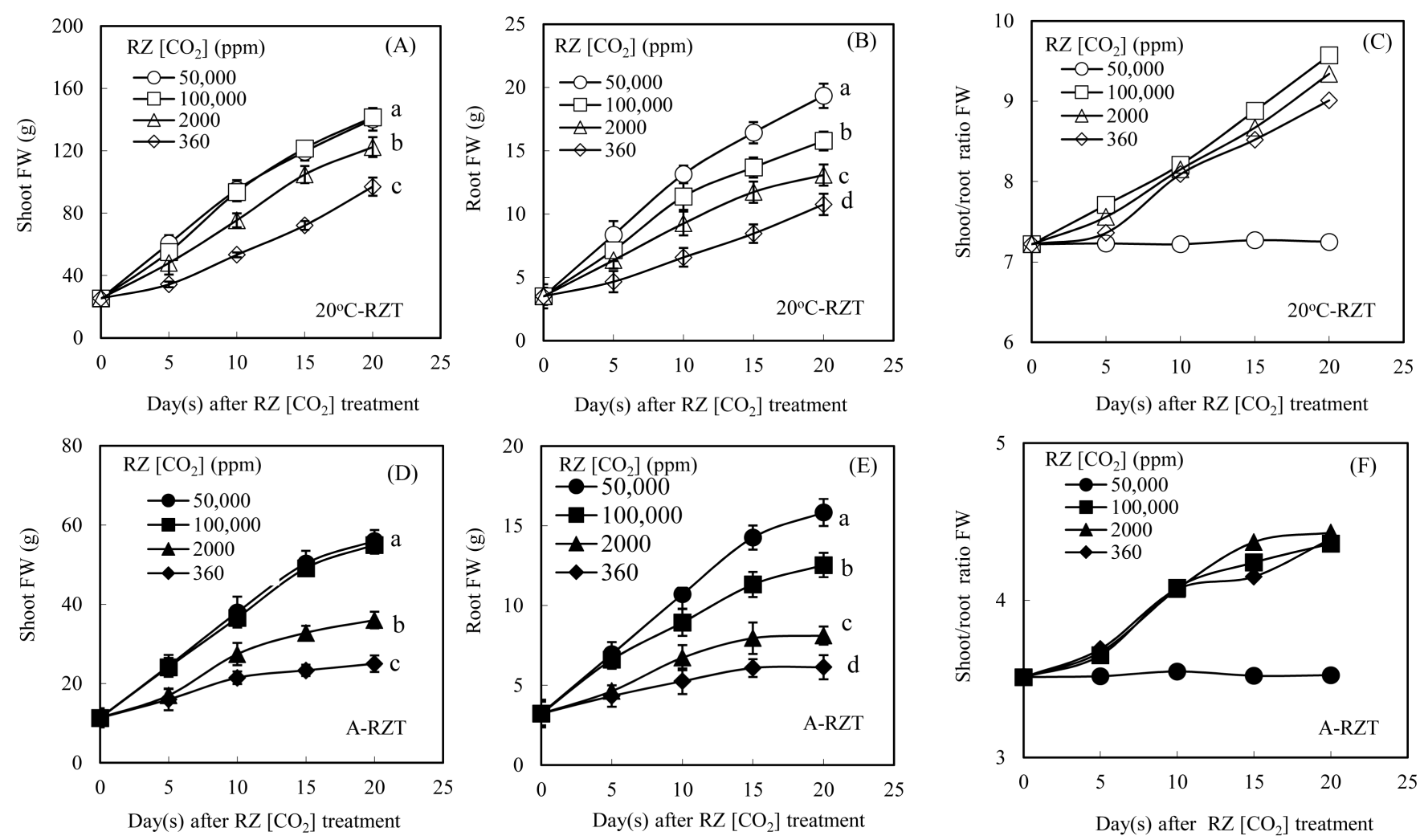

Figure 3. Changes in shoot FW ((A), (D)), root FW ((B), (E)) and shoot/root ratio FW ((C), (F)) of lettuce plans grown under different elevated RZ $\left[\mathrm{CO}_{2}\right]$ at $20^{\circ} \mathrm{C}-\mathrm{RZT}$ and A-RZT. Each mean is 5 measurements of 5 different leaves. Vertical bars represent the standard errors. Means with different letters on day 20 are statistically different $(P<0.05)$ as determined by Tukey's multiple comparison test.
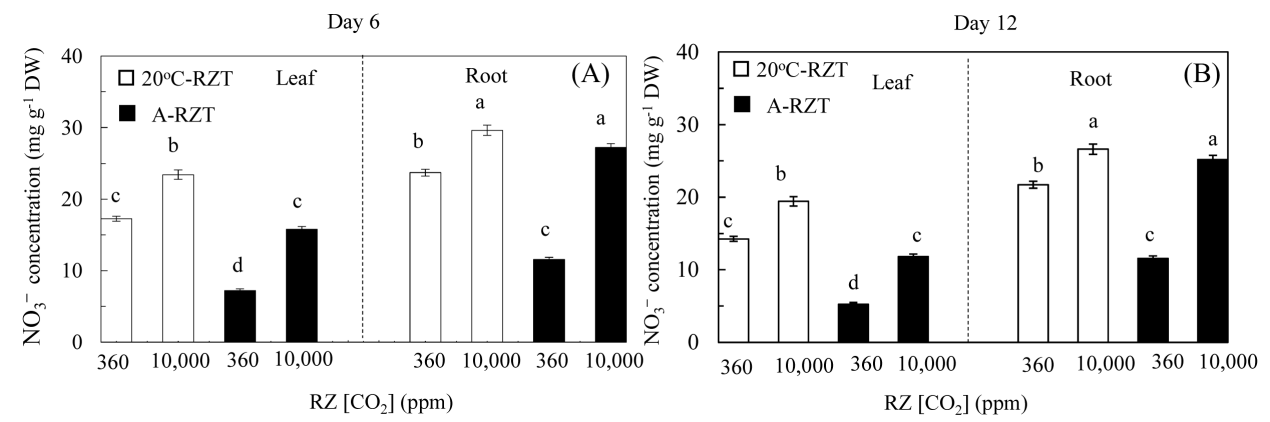

Figure 4. $\mathrm{NO}_{3}^{-}$concentration of leaves and roots after different $\mathrm{RZT}$ and $\left[\mathrm{CO}_{2}\right]$ treatments for 6 (A) and 12 days (B). Vertical bars represent the standard errors. Means with different letters are statistically different $(P<0.05 ; \mathrm{n}=5)$ as determined by Tukey's multiple comparison test.

The concentration of TRN was significantly higher in plants grown under elevated $\mathrm{RZ}\left[\mathrm{CO}_{2}\right]$ of $10,000 \mathrm{ppm}$ than under ambient $\mathrm{RZ}\left[\mathrm{CO}_{2}\right]$ of $360 \mathrm{ppm}$ at both growth stages (Figure 5). At each RZ $\left[\mathrm{CO}_{2}\right], 20^{\circ} \mathrm{C}$-RZT plants had higher concentration of TRN than those of A-RZT plants. Furthermore, the concentrations of TRN in leaves were higher than in roots for all plants.

NRA was higher in root than in leaf for each given $\mathrm{RZ}\left[\mathrm{CO}_{2}\right]$ especially under A-RZT at both growth stages of 6 (Figure 6(A)) and 12 (Figure 6(B)) days after treatments. 

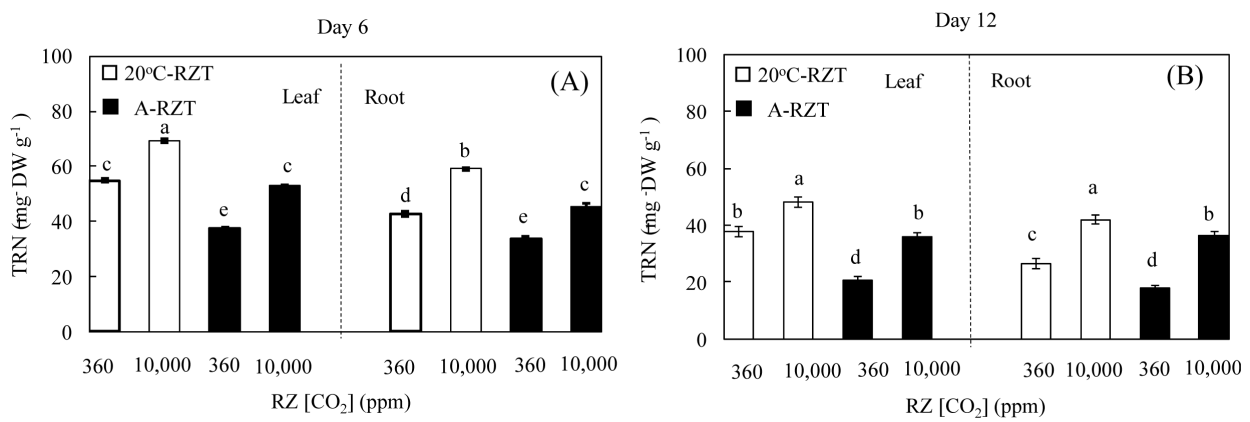

Figure 5. TRN concentration of leaves and roots after different $\mathrm{RZT}$ and $\left[\mathrm{CO}_{2}\right]$ treatments for 6 (A) and 12 days (B). Vertical bars represent the standard errors. Means with different letters are statistically different $(P<0.05 ; \mathrm{n}=5)$ as determined by Tukey's multiple comparison test.
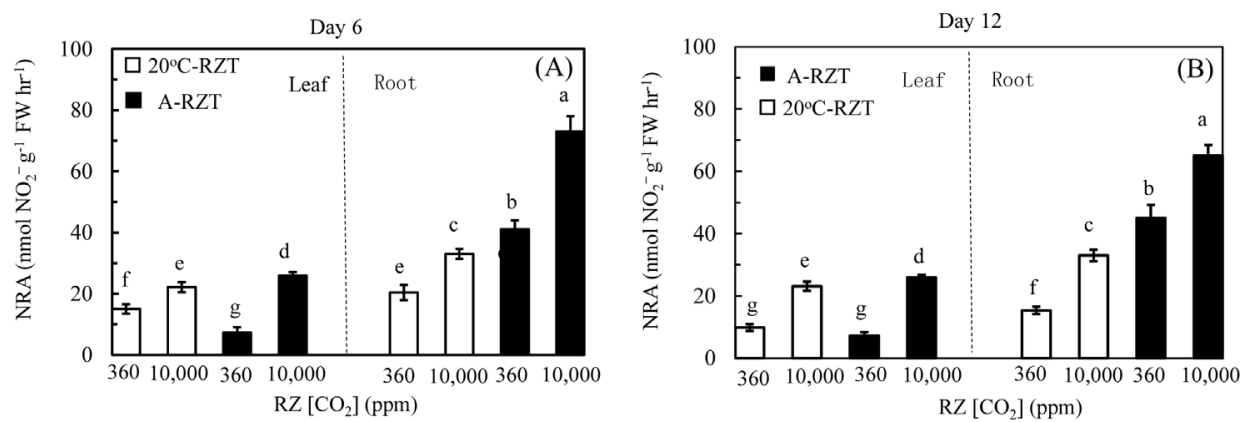

Figure 6. NRA of leaves and roots after different RZT and $\left[\mathrm{CO}_{2}\right]$ treatments for $6(\mathrm{~A})$ and 12 days (B). Vertical bars represent the standard errors. Means with different letters are statistically different $(P<0.05 ; \mathrm{n}=4)$ as determined by Tukey's multiple comparison test.

For both leaf and root, NRA was higher in plants under RZ $\left[\mathrm{CO}_{2}\right]$ of 10,000 ppm than under RZ $\left[\mathrm{CO}_{2}\right]$ of $360 \mathrm{ppm}$.

\section{Discussion}

We have previously reported that elevated $\mathrm{RZ}\left[\mathrm{CO}_{2}\right]$ stimulated photosynthesis of aeroponically grown lettuce plants and enhanced water use efficiency and plant growth, with greater increase at higher ambient temperature [8] and hot A-RZT compared to cool ambient temperature and cool-RZT [9]. Elevated levels of atmospheric $\mathrm{CO}_{2}$ promote not only leaf photosynthesis but also photoassimilate partitioning to roots which stimulate root development [24] [25]. This study showed that elevated $\mathrm{RZ}\left[\mathrm{CO}_{2}\right]$ also promoted root development and root growth with longer total root length (Figure $1(\mathrm{~A})$ ), greater number of root tips (Figure (1B)), larger root surface area and greater root biomass accumulation (Figure $2(\mathrm{~B})$ and Figure $2(\mathrm{E})$ ) at both $20^{\circ} \mathrm{C}-\mathrm{RZT}$ and A-RZT. Furthermore, the magnitudes of increased total root length, root tips, root surface area and root biomass were greater in A-RZT plant than in $20^{\circ} \mathrm{C}-\mathrm{RZT}$ plants.

It was reported that increased plant growth at elevated atmospheric $\mathrm{CO}_{2}$ depends on the source/sink ratio and "sink capacity" of plants [26]. In the present study, elevated $\mathrm{RZ}\left[\mathrm{CO}_{2}\right]$ increased from 10,000 to $50,000 \mathrm{ppm}$ did not result in further increases in leaf area (Figure 2), shoot and root FW (Figure 3) and DW (data not shown) in both 
$20^{\circ} \mathrm{C}$-RZT and A-RZT. However, root productivity (root FW and DW) increased further under elevated $\mathrm{RZ}\left[\mathrm{CO}_{2}\right]$ of 50,000 ppm with constant shoot/root ratio throughout the entire 3 weeks of treatment compared to plants grown under other RZ $\left[\mathrm{CO}_{2}\right]$ of 360 , 2000 and 10,000 ppm at both RZTs (Figure 2(C) and Figure 2(F)). These results support the fact that plants with larger root systems under elevated $\mathrm{RZ}\left[\mathrm{CO}_{2}\right]$ enhanced the capacity of utilizing photosynthetic products with greater amount of photoassimilate portioning to their roots [8] [9]. We have previously reported that lettuce plants grown at $20^{\circ} \mathrm{C}$-RZT had not only greater root biomass but also longer total length, greater number of tips and larger surface area as compared with A-RZT plants [28]. In the present study, elevated $\mathrm{RZ}\left[\mathrm{CO}_{2}\right]$ also promoted root growth and development at both $20^{\circ} \mathrm{C}$-RZT and A-RZT. Our previous study also showed that plants grown at $20^{\circ} \mathrm{C}-\mathrm{RZT}$ had smaller average diameter of roots compared to those grown at A-RZT [28]. However, in this study, regardless of $\mathrm{RZ}\left[\mathrm{CO}_{2}\right]$ treatments, there were no differences in average root diameter at either $20^{\circ} \mathrm{C}$-RZT or A-RZT (Figure $1(\mathrm{D})$ ). The temperature of a sink could affect its metabolic rate and thus its capacity to utilize carbohydrate [27][29]. Elevated $\mathrm{RZ}\left[\mathrm{CO}_{2}\right]$ could also affect the physiological activities of roots and thus alter the pattern of photoassimilate partitioning. This merits our further studies.

A well-developed large root system generally increased the capacity of plants to exploit water and mineral nutrients especially under other adversely environmental conditions [13] [14]. It has been reported that elevated $\mathrm{RZ}\left[\mathrm{CO}_{2}\right]$ could enhance the growth of tomato (Lycopersicon esculentum) seedlings, especially under stress conditions such as salinity and high temperature. Greater number of fine roots in larger root system (Figure 1) which resulted in a greater amount of $\mathrm{NO}_{3}^{-}$uptake especially at A-RZT under elevated $\mathrm{RZ}\left[\mathrm{CO}_{2}\right]$ at two different growth stages of 6 and 12 days after treatment, was observed in the present study (Figure 4). Enriched rhizosphere $\mathrm{CO}_{2}$ promoted the uptake of $\mathrm{NO}_{3}^{-}$by roots was reported in hydroponically grown tomato (L. esculentum) plants [14]. The $\mathrm{NO}_{3}^{-}$uptake could be associated with an exchange for $\mathrm{HCO}_{3}^{-}$. Elevated $\mathrm{RZ}$ in the form of DICincreased $\mathrm{NO}_{3}^{-}$uptake [11].

The elevated DIC stimulated respiratory electron transport and increased the incorporation of $\mathrm{NO}_{3}^{-}$into amino acids [11]. In the study of crisphead-type lettuce (L. sativa L. cv. "Wintergreen") grown aeroponically under different $\mathrm{RZ}\left[\mathrm{CO}_{2}\right]$ at two different air temperatures [8], we previously found that $\mathrm{NO}_{3}^{-}$and the TRN concentrations of shoots were higher in all plants under elevated $\mathrm{RZ}\left[\mathrm{CO}_{2}\right]$ than under ambient $\mathrm{RZ}\left[\mathrm{CO}_{2}\right]$ at $28^{\circ} \mathrm{C} / 22^{\circ} \mathrm{C}$ and $36^{\circ} \mathrm{C} / 30^{\circ} \mathrm{C}$. Shoot $\mathrm{NO}_{3}^{-}$and TRN concentrations were higher at $28^{\circ} \mathrm{C} / 22^{\circ} \mathrm{C}$ than at $36^{\circ} \mathrm{C} / 30^{\circ} \mathrm{C}$ at each RZ $\left[\mathrm{CO}_{2}\right]$. As discussed earlier, in this study, elevated $\mathrm{RZ}\left[\mathrm{CO}_{2}\right]$ stimulated the development of lettuce roots (Figure 1). These results further support that aeroponically grown plants under elevated $\mathrm{RZ}\left[\mathrm{CO}_{2}\right]$ that have a large root system with continual spraying nutrient under elevated $\mathrm{RZ}\left[\mathrm{CO}_{2}\right]$, increased $\mathrm{NO}_{3}^{-}$(Figure 4) and TRN concentration (Figure 5) in both leaves and roots. $\mathrm{NO}_{3}^{-}$ concentrations in all plants were higher in roots than in leaves. However, the concentration of TRN of all the lettuce plants was higher in leaves than in roots (Figure 5). Photosynthesis is closely related to TRN of the plant as the components of photosyn- 
thetic machinery contain a large amount of leaf TRN [30]. It was reported that leaf TRN concentration per unit area decreased under elevated atmospheric $\mathrm{CO}_{2}$, which may be due to their fast growth rates [31]. Reduction of TRN concentration resulted from the fact that both the rate of $\mathrm{NO}_{3}^{-}$uptake and assimilation were not kept pace with photosynthesis and growth under elevated $\left[\mathrm{CO}_{2}\right][32]$.

In our previous study, it was found that lettuce plants grown under elevated RZ $\left[\mathrm{CO}_{2}\right]$, had lower light saturated stomatal conductance, $g_{\text {s sat }}$ but higher light saturated photosynthetic $\mathrm{CO}_{2}$ assimilation rate, $A_{\text {sat }}$. Higher $A_{\text {sat }}$ under elevated RZ $\left[\mathrm{CO}_{2}\right]$ could partially be resulted from the incorporation of DIC that improved the incorporation of $\mathrm{N}$ into amino acids in the roots as a consequence of a greater supply of anaplerotic carbon for protein synthesis [8] [9]. Our previous study also showed that higher $\mathrm{NO}_{3}^{-}$ uptake and thus higher TRN concentration when lettuce plants were grown under elevated $\mathrm{RZ}\left[\mathrm{CO}_{2}\right]$ compared to those grown under ambient $\mathrm{RZ}\left[\mathrm{CO}_{2}\right]$ at both cool and ambient fluctuating RZT [9].

Assimilation of $\mathrm{NO}_{3}^{-}$into organic $\mathrm{N}$ containing compounds involves the reduction of $\mathrm{NO}_{3}^{-}$to $\mathrm{NO}_{2}^{-}$via the cytosolic enzyme $\mathrm{NR}$ that is an $\mathrm{NO}_{3}^{-}$inducible enzyme [33]-[35]. It was surprising to note that NRA was much lower in leaves that in roots under each given $\mathrm{RZ}\left[\mathrm{CO}_{2}\right]$ especially under A-RZT after both 6 (Figure 6(A)) and 12 (Figure 6(B)) days of treatments. The elevated $\mathrm{RZ}\left[\mathrm{CO}_{2}\right]$ of $10,000 \mathrm{ppm}$ enhanced NRA in both leaves and roots compared to plants grown under $\mathrm{RZ}\left[\mathrm{CO}_{2}\right]$ of $360 \mathrm{ppm}$. The reduction of $\mathrm{NO}_{3}^{-}$could take place either in roots or in leaves or both [36] [37]. Higher NRA could be due to the higher accumulation of $\mathrm{NO}_{3}^{-}$in roots under A-RZT and this result supported that elevated $\mathrm{RZ}\left[\mathrm{CO}_{2}\right]$ and A-RZT resulted in higher assimilation in the roots compared to ambient $\mathrm{RZ}\left[\mathrm{CO}_{2}\right]$ and $20^{\circ} \mathrm{C}$-RZT. It was reported that the decrease of photosynthesis due to stomatal closure may result in reduction in NRA [33]. In the study with wheat (Triticum durum L.) plants, it was shown that a drought-induced decrease of the leaf internal $\mathrm{CO}_{2}$ concentration partially triggered the decrease in NRA [38]. However, there was no liner relationship between $A_{\text {sat }}$ and $g_{\text {ssat }}$ in lettuce plants grown under different RZ $\left[\mathrm{CO}_{2}\right]$ and RZTs [8] [9]. These results further support that the improved incorporation of $\mathrm{N}$ into amino acids in the roots resulting from greater supplies of anaplerotic carbon for protein synthesis partially contributed to higher $A_{\text {sat }}$ at both RZTs [11]. There is a positive linear relationship between leaf TRN and ribulose-1,5-bisphosphate carboxylase/oxygenase (Rubisco) in mature leaves. Reductions of these two parameters result in decreased photosynthesis [30] [39] [40]. Higher $\left[\mathrm{CO}_{2}\right]$ in the vicinity of chloroplasts normally favours Rubisco carboxlyation over oxygenation [40]. Under elevated atmospheric $\left[\mathrm{CO}_{2}\right]$, enhanced photosynthesis is partially due to the reduction of photorespiration [40]. In future, high temperatures or water deficient have been predicted, elevated atmospheric $\left[\mathrm{CO}_{2}\right]$ which reduced photorespiration may be beneficial. Based upon our observation that increasing photosynthetic $\mathrm{CO}_{2}$ assimilation under elevated $\mathrm{RZ}\left[\mathrm{CO}_{2}\right]$ may also result in reduction of photorespiration, especially under higher temperatures [41]. 


\section{Acknowledgements}

All experiment work on subtropical and temperate vegetables grown aeroponically was supported by the Academic Research Fund (Grant reference numbers: RP12/01, RI7/05 HJ, Ministry of Education, Singapore and Singapore Millennium Foundation (Project code: SMF-Farming System).

\section{References}

[1] He, J. (2010) Mineral Nutrition of Aeroponically Grown Subtropical and Temperate Crops in the Tropics with Manipulation of Root-Zone Temperature at Different Growth Irradiances. Plant Stress, 4, 14-30.

[2] He, J. (2009) Impact of Root-Zone Temperature on Photosynthetic Efficiency of Aeroponically Grown Temperate and Subtropical Vegetable Crops in the Tropics. In: Buchner, Th.B. and Ewingen, N.H., Eds., Theory and Applications in Energy, Biotechnology and Nanotechnology, Nova Science Publishers Inc., New York, Chapter 4, 111-143.

[3] Yang, J.C. (2011) Relationships of Rice Root Morphology and Physiology with the Formation of Grain Yield and Quality and the Nutrient Absorption and Utilization. Scientia Agricultura Sinica, 1, 36-46.

[4] He, J. and Lee S.K. (1998) Growth and Photosynthetic Characteristics of Lettuce (Lactuca sativa L.) Grown under Fluctuating Hot Ambient Temperatures with the Manipulation of Cool Rootzone Temperature. Journal of Plant Physiology, 152, 387-391. http://dx.doi.org/10.1016/S0176-1617(98)80252-6

[5] He, J. and Lee, S.K. (1998) Growth and Photosynthetic Responses of Three Aeroponically Grown Lettuce Cultivars (Lactuca sativa L.) to Different Rootzone Temperatures and Growth Irradiances under Tropical Aerial Condition. The Journal of Horticultural Science and Biotechnology, 73, 173-180. http://dx.doi.org/10.1080/14620316.1998.11510961

[6] He, J., Austin, P.T., Nichols, M.A. and Lee, S.K. (2004) Effect of Root-Zone $\mathrm{CO}_{2}$ on Productivity and Photosynthesis in Aeroponically Grown Lettuce Plants. Acta Horticulturae, 648, 39-45. http://dx.doi.org/10.17660/ActaHortic.2004.648.5

[7] He, J., Austin, P.T., Nichols, M.A. and Lee, S.K. (2007) Elevated Root-Zone $\mathrm{CO}_{2}$ Protects Lettuce Plants from Midday Depression of Photosynthesis. Environmental and Experimental Botany, 61, 94-110. http://dx.doi.org/10.1016/j.envexpbot.2007.04.001

[8] He, J., Austin, P.T., Nichols, M.A. and Lee, S.K. (2010) Effects of Elevated Root-Zone $\mathrm{CO}_{2}$ and Air Temperature on Photosynthetic Gas Exchange, Nitrate Uptake and Total Reduced Nitrogen Content in Aeroponically Grown Lettuce Plants. Journal of Experimental Botany, 61, 3959-3969. http://dx.doi.org/10.1093/jxb/erq207

[9] He, J., Qin, L. and Lee, S.K. (2013) Root-Zone $\mathrm{CO}_{2}$ and Root-Zone Temperature Effects on Photosynthesis and Nitrogen Metabolism of Aeroponically Grown Lettuce (Lactuca sativa L.) Plants in the Tropics. Photosynthetica, 52, 330-340. http://dx.doi.org/10.1007/s11099-013-0030-5

[10] He, J. (2015) Elevated Root-Zone $\mathrm{CO}_{2}$ on Photosynthesis of Vegetable Crops at Different Air and Root-Zone Temperatures. In: Khan, N., Ed., Photosynthesis: Functional Genomics, Physiological Processes and Environmental Issues, Nova Science Publishers, Inc., New York, Chapter 4, 25-54.

[11] Cramer, M.D., Lewis, O.A.M. and Lips, S.H. (1993) Inorganic Carbon Dioxide Fixation and Metabolism in Maize Roots as Affected by Nitrate and Ammonium Nutrition. Physiologia Plantarum, 89, 632-639. http://dx.doi.org/10.1111/j.1399-3054.1993.tb05226.x 
[12] Cramer, M.D. and Lips, S.H. (1995) Enriched Rhizosphere $\mathrm{CO}_{2}$ Concentrations Can Ameliorate the Influence of Salinity on Hydroponically Grown Tomato Plants. Physiologia Plantarum, 94, 425-432. http://dx.doi.org/10.1111/j.1399-3054.1995.tb00949.x

[13] Cramer, M.D. and Richards, M.B. (1999) The Effect of Rhizosphere Dissolved Inorganic Carbon on Gas Exchange Characteristics and Growth Rates of Tomato Seedlings. Journal of Experimental Botany, 50, 79-87. http://dx.doi.org/10.1093/jxb/50.330.79

[14] Viktor A. and Cramer, M.D. (2003) Variation in Root-Zone $\mathrm{CO}_{2}$ Concentration Modifies isotopic Fractionation of Carnon and Nitrogen in Tomato Seedlings. New Phytologist, 157, 45-54. http://dx.doi.org/10.1046/j.1469-8137.2003.00650.x

[15] Cramer, M.D., Shane, M.W. and Lambers, H. (2005) Physiological Changes in White Lupin Associated with Variation in Root-Zone $\mathrm{CO}_{2}$ Concentration and Cluster-Root P Mobilization. Plant, Cell \& Environment, 28, 1203-1217. http://dx.doi.org/10.1111/j.1365-3040.2005.01358.x

[16] Ford, C.R., Wurzburger, N., Hendrick, R.L. and Teskey, R.O. (2007) Soil DIC Uptake and Fixation in Pinus taeda Seedlings and Its C Contribution to Plant Tissues and Ectomycorrhizal Fungi. Tree Physiology, 27, 375-383. http://dx.doi.org/10.1093/treephys/27.3.375

[17] Berveiller, D. and Damesin, C. (2008) Carbon Assimilation by Tree Stems: Potential Involvement of Phosphoenolpyruvate Carboxylase. Trees, 22, 149-157. http://dx.doi.org/10.1007/s00468-007-0193-4

[18] Qin L., He, J., Lee, S.K. and Dodd, I.C. (2007) An Assessment of Ethylene Mediation of Lettuce (Lactuca sativa) Root Growth at High Temperatures. Journal of Experimental Botany, 58, 3017-3024. http://dx.doi.org/10.1093/jxb/erm156

[19] Tan, L.P., He, J. and Lee, S.K. (2002) Effects of Root-Zone Temperature on the Root Development and Nutrient Uptake of Lactuca sativa L. cv "Panama" Grown in an Aeroponic System in the Tropics. Journal of Plant Nutrition, 25, 297-314. http://dx.doi.org/10.1081/PLN-100108837

[20] Minchin, P.E.H. and Thorpe, M.R. (1996) What Determines Carbon Partitioning between Competing Sinks? Journal of Experimental Botany, 47, 1293-1296. http://dx.doi.org/10.1093/jxb/47.Special Issue.1293

[21] Kuo, T.-M., Warner, R.L. and Kleinhofs, A. (1982) In Vitro Stability of Nitrate Reductase from Barley Leaves. Phytochemisry, 21, 531-533. http://dx.doi.org/10.1016/0031-9422(82)83134-8

[22] Kaiser, W.M. and Huber, S.C. (1997) Correlation between Apparent Activation State of Nitrate Reductase (NR), NR Hysteresis and Degradation of NR Protein. Journal of Experimental Botany, 48, 1367-1374. http://dx.doi.org/10.1093/jxb/48.7.1367

[23] Allen, S.E. (1989) Analysis of Vegetation and Other Organic Materials. In: Allen, S.E., Ed., Chemical Analysis of Ecological Materials, Blackwell Scientific Publication, Oxford, 46-61.

[24] Norby, R.J., Gunderson, C.A., Wullschleger, S.D., O’Neill, E.G. and McCracken, M.K. (1992) Productivity and Compensatory Responses of Yellow-Poplar Trees in Elevated $\mathrm{CO}_{2}$. Nature, 357, 322-324. http://dx.doi.org/10.1038/357322a0

[25] Norby, R.J. (1994) Issues and Perspectives for Investigating Root Responses to Elevated Atmospheric Carbon Dioxide. Plant Soil, 165, 9-20. http://dx.doi.org/10.1007/BF00009958

[26] Makino, A. and Mae, T. (2004) Photosynthesis and Plant Growth at Elevated Levels of $\mathrm{CO}_{2}$. Plant and Cell Physiology, 40, 999-1006. http://dx.doi.org/10.1093/oxfordjournals.pcp.a029493

[27] Ainsworth, E.A. and Rogers, A. (2007) The Response of Photosynthesis and Stomatal Conductance to Rising $\left[\mathrm{CO}_{2}\right]$ : Mechanisms and Environmental Interactions. Plant, Cell \& En- 
vironment, 30, 258-270. http://dx.doi.org/10.1111/j.1365-3040.2007.01641.x

[28] He, J., Tan, L.P. and Lee S.K. (2009) Root-Zone Temperature Effects on Photosynthesis, ${ }^{14} \mathrm{C}$-Photoassimilate Partitioning and Growth of Temperate Lettuce (Lactuca sativa cv. "Panama") Grown in the Tropics. Photosynthetica, 47, 95-103.

http://dx.doi.org/10.1007/s11099-009-0015-6

[29] Schurr, U., Heckenberger, U., Herdel, K., Walter, A. and Feil, R. (2000) Leaf Development in Ricinus communis during Drought Stress: Dynamics of Growth Processes, of Cellular Structure and of Sink-Source Transition. Journal of Experimental Botany, 51, 1515-1529. http://dx.doi.org/10.1093/jexbot/51.350.1515

[30] Evans, J.R. (1989) Photosynthesis and Nitrogen Relationships in Leaves of $\mathrm{C}_{3}$ Plants. Oecologia, 78, 9-19. http://dx.doi.org/10.1007/BF00377192

[31] Ellsworth, D.S., Reich, P.B., Naumburg, E.S., Koch, G.W., Kubiske, M.E. and Smith, S.D. (2004) Photosynthesis, Carboxylation and Leaf Nitrogen Responses of 16 Species to Elevated $\mathrm{pCO}_{2}$ across Four Free-Air $\mathrm{CO}_{2}$ Enrichment Experiments in Forest, Grassland and Desert. Global Change Biology, 10, 2121-2138.

http://dx.doi.org/10.1111/j.1365-2486.2004.00867.x

[32] Pettersson, R. and McDonald, J.S. (1994) Effects of Nitrogen Supply on the Acclimation of Photosynthesis to Elevated $\mathrm{CO}_{2}$. Photosynthesis Research, 39, 389-400. http://dx.doi.org/10.1007/BF00014593

[33] Van der Merwe, C.A. and Cramer, M.D. (2000) The Influence of Dissolved Inorganic Carbon in the Root-Zone on Nitrogen Uptake and the Interaction between Carbon and Nitrogen Metabolism. In: Louçao, M.A. and Lips, S.H., Eds., Nitrogen in a Sustainable Ecosystem-From the Cell to the Plant, Backhuys Publishers, Leiden, 145-151.

[34] Cookson, S.J., Williams, L.E. and Miller, A.J. (2005) Light-Dark Changes in Cytosolic Nitrate Pools Depend on Nitrate Reductase Activity in Arabidopsis Leaf Cells. Plant Physiology, 138, 1097-1105. http://dx.doi.org/10.1104/pp.105.062349

[35] Kaiser, W.M. and Brendel-Benisch, E. (1991) Rapid Modulation of Spinach Leaf Nitrate Reductase Activity by Photosynthesis. Modulation in Vivo by $\mathrm{CO}_{2}$ Availability. Plant Physiology, 96, 363-367. http://dx.doi.org/10.1104/pp.96.2.363

[36] Cen, Y.P. and Layzell, D.B. (2003) In Vivo Gas Exchange Measurement of the Site and Dynamics of Nitrate Reduction in Soybean. Plant Physiology, 131, 1147-1156. http://dx.doi.org/10.1104/pp.102.019430

[37] Scheurwater, I., Koren, M., Lambers, H. and Atkin, O.K. (2002) The Contribution of Roots and Shoots to Whole Plant Nitrate Reduction in Fast- and Slow-Growing Grass Species. Journal of Experimental Botany, 55, 1635-1642. http://dx.doi.org/10.1093/jxb/erf008

[38] Fresneau, C., Ghhahghaie, J. and Cornic, G. (2007) Drought Effect on Nitrate Reductase and Sucrose-Phosphate Synthase Activities in Wheat (Triticum durum L.): Role of Leaf Internal $\mathrm{CO}_{2}$. Journal of Experimental Botany, 58, 2983-2992.

http://dx.doi.org/10.1093/jxb/erm150

[39] Li, Y., Gao, Y., Xu, X., Shen, Q. and Guo, S. (2009) Light-Saturated Photosynthetic Rate in High-Nitrogen Rice (Oryza sativa L.) Leaves Is Related to Chloroplastic $\mathrm{CO}_{2}$ Concentration. Journal of Experimental Botany, 60, 2351-2360. http://dx.doi.org/10.1093/jxb/erp127

[40] Peterson, R.B. (1983) Estimation of Photorespiration Based on the Initial Rate of Postillumination $\mathrm{CO}_{2}$ Release: II. Effects of $\mathrm{O}_{2}, \mathrm{CO}_{2}$, and Temperature. Plant Physiology, 73, 983988. http://dx.doi.org/10.1104/pp.73.4.983

[41] Peterhansel, C. and Maurino, V.G. (2011) Photorespiration Redesigned. Plant Physiology, 155, 49-55. http://dx.doi.org/10.1104/pp.110.165019 
Submit or recommend next manuscript to SCIRP and we will provide best service for you:

Accepting pre-submission inquiries through Email, Facebook, LinkedIn, Twitter, etc.

A wide selection of journals (inclusive of 9 subjects, more than 200 journals)

Providing 24-hour high-quality service

User-friendly online submission system

Fair and swift peer-review system

Efficient typesetting and proofreading procedure

Display of the result of downloads and visits, as well as the number of cited articles

Maximum dissemination of your research work

Submit your manuscript at: http://papersubmission.scirp.org/

Or contact ajps@scirp.org 